\title{
School Psychology on the Formation of the Social Educator: Assessment of the Professional Profile
}

\author{
Pollianna Galvão, ${ }^{1,2}$, Daniel Carvalho de Matos $^{1,2}$, Wirna Lima Gomes ${ }^{3}$ \\ ${ }^{1}$ Department of Psychology, Ceuma University, São Luís, Brazil \\ ${ }^{2}$ Federal University of Maranhão, NúcleoEvoluir-Counseling in Educational and School Psychology, São Luís, Brazil \\ ${ }^{3}$ The Scientific Initiation Program in Psychology, Ceuma University, São Luís, Brazil \\ Email: polliannagalvao@yahoo.com.br,dcmatos23@hotmail.com,wirnalima_psic7@hotmail.com
}

How to cite this paper: Galvão, P., de Matos, D. C., \& Gomes, W. L. (2018). School Psychology on the Formation of the Social Educator: Assessment of the Professional Profile. Creative Education, 9, 249271.

https://doi.org/10.4236/ce.2018.92016

Received: December 27, 2017

Accepted: February 10, 2018

Published: February 13, 2018

Copyright $\odot 2018$ by authors and Scientific Research Publishing Inc. This work is licensed under the Creative Commons Attribution International License (CC BY 4.0).

http://creativecommons.org/licenses/by/4.0/

\begin{abstract}
In Brazilian scenario, the profession of the social educator is recent in the non-formal educative spaces, including institutions which act in benefit of the poorest segments of the population. With the intent to contribute to the discussion on the formation of the social educator, this manuscript seeks to investigate the professional profile resources of social educators from a Brazilian Non-Governmental Organization (NGO) and the possibilities of contribution from the School and Educational Psychology to the consolidation of this profession's identity. In this study, it was utilized the theoretical-conceptual perspective of historical-cultural Psychology in articulation with the competence approach. Six social educators participated in this study. The first research step consisted of the review and expansion of the social educator's professional profile proposed by Soares (2008) through a literature review in School and Educational Psychology and institutional visits to a Brazilian $\mathrm{NGO}$, which categorizes six competence resources for the composition of the social educator's profile: 1 ) theoretical and conceptual performances; 2) technical and scientific competences; 3) practical knowledge competences; 4) interpersonal competences; 5) ethical competences; 6) esthetical competences. The second step involved the application of the instrument in six social educators. The results indicated predominance in relation to the practical knowledge, interpersonal, ethical and esthetical competences. In counterpoint, the theoretical and conceptual competences and technical and scientific competences were the less evidenced ones, suggesting a profile still undeveloped through paths of initial and continuous formation specific in the field of social education. Against this challenge in research, it is understood that School Psychology may bring contributions to non-formal educative spaces of Third
\end{abstract}


Sector to favor the development and consolidation of the professional identity of the social educator, of the theoretical and conceptual production on the formation and actuation of social educators, as well as the expansion of School and Educational Psychology to differentiated educative spaces.

\section{Keywords}

School and Educational Psychology, Social Educator, Formation, Professional Profile

\section{Introduction}

For a long time School and Educational Psychology was invited to make contributions at educational contexts predominantly regarding demands related to school issues and learning difficulties (Neves, 2011). Nevertheless, the emergence of alternative educational spaces with an emphasis on human development favored the possibility of intervention for the school psychologist. The Non-governmental Educational Organizations (NGOs) are examples of socially engaged institutions with the human formation, with the purpose of attenuating the history of social exclusion by informal education (Galvão, 2014; Gohn, 2006, 2011). The School Psychology, as a study field of knowledge, actuation and professional formation, conceives the educational realities in a complex and multi-determined fashion, which conducts to actuations at different levels. Among these levels it is important to promote psychological interventions for the strengthening of the competences of human development agents: teachers and social educators (Marinho-Araujo, 2014).

In Brazil, the beginning of educational services delivery emerged between the 70 's and 80 's, with different pedagogical proposals. In the scenario of non-state institutions during this period, the emphasis was directed to informal educational spaces, which demanded the achievement of specific educational practices, committed to the development of individuals related to a socioeconomically unprivileged population (Caro \& Guzzo, 2004; Gohn, 2006, 2009).

Since the beginning of institutionalization of NGOs in the country, there has always been a connection to the educational field, whose missions were dedicated to reducing social inequalities and the difficult access to school banks through primary and/or compensatory measures (Oliveira \& Haddad, 2001). During the 90's, there was a huge advance in educational institutions of the third sector, especially through LDB (Law of Guidelines and Bases of National Education), Law number 9.394/1996, by which the legal opening of institutions organized by civil society is established.

These changes in the Brazilian education scenario produced a concern related to the formation of professionals, who are involved in programs and social projects and are known, in the education literature, as social educators (Romans, 
Petrus, \& Trilla, 2003). The professional profile of social educators is still not quite well established, considering the necessary competences to deal with complex social issues related to their work. The lack of proper formation, initial and continued, for competent performance is one of the main challenges, which interpose in the discussion of public formative policies, imperative to this new worker (Soares \& Marinho-Araujo, 2010).

Several authors claim that the Brazilian academic environment still has not paid proper attention to the formation of social educators, before their significant work responsibility, and its political and social relevance in a scenario of a country, such as Brazil, with income inequalities (Canastra \& Malheiro, 2009; Caro \& Guzzo, 2004; Gohn, 2006, 2009; Ribeiro, 2006; Rodrigues, 2005; Soares \& Marinho-Araujo, 2010). In fact, what are observed are "inadequacies of well-intended educators (professionals), considering their lack of formation, support and even advisory from professionals from several work fields" (Caro \& Guzzo, 2004: p. 16).

School Psychology shall be committed to this discussion over the social educator's profile to contribute to the establishment of strategies of professional formation under the perspective of psychological development of the adult. For this, it is important to be clear about the conception of human development, which subsidizes the initial and continued formative models of profession.

\section{Human Development in the Perspective of Historical-Cultural Psychology}

The historical-cultural approach states that superior psychological phenomena have their genesis constituted through the mediation between the social history, in constant changing through time and space, and the subjects' individual experience, established through social relations (Leontiev, 2004; Luria, 1990; Vygotsky, 1998, 2000, 2004). Under this perspective, the contemporary processes pertinent to human development, like the educator's formation to work, demands an analysis on social and cultural issues, which influence the path of human life (González Rey, 2003).

Commonly, it is attributed to the concept of "work" a sense of repetition of tasks, pertinent and necessary doings to the survival of the human species, and which encompass distinct nuances in several periods of the historical evolution of society. It is not hard to perceive, currently, that the given direction to the formative aspects in spaces of work adheres emphasis to training, to tasks reproduction, notwithstanding a conception of work organization as a privileged locus to complex processes of adult human development.

The historical-cultural theory from Psychology conceives the notion of work and the angular stone to the development of psychological characteristics, which are typically human. Influenced by the Marxist perspective, Leontiev (2004) defines that the work is a process, which establishes distinct kinds of relationship between human and the nature in the path of history of humanity and the pro- 
ductive activities are locus for the understanding of psychological human genesis. According to this author, there exist a human pre-consciousness, which is found in cognitive processes of animals and, through this, it was possible the evolution of the human species. Nevertheless, it is the quality of social work that will establish the differences in specificities of human psychological functions related to the most elementary cognitive processes.

The qualitative development of psychic functions, which demarcate distinction with the animals, is in the differences attributed to the social work organization among several species. The work is characterized as an activity performed by collectivity and which tends to provide actions over its environment, mediated by the use of instrument and by communication. The language and the word constitute, in this perspective, elements to the formation of superior psychological processes through the need that men have in relation to the exercise of social work. This way, the language would represent the practical consciousness of men by the double function that adheres to human action: the productive and communicative function.

The emergence of work, for Marx and Engels (cited by Leontiev, 2004), is considered as the foundation of social existence, and not merely one of the ways to develop the relations in society. In the dialectical materialist perspective, the work emerged through the manufacturing of instruments and, through them the typically human characteristics were constituted, such as language and consciousness.

Leontiev (2004) conducted a deeper discussion on the evolution of human intellectual processes through their understanding of the human activity and its relation to the Marxist notion of work. For the mentioned author, "the structure of human consciousness is regularly connected to the structure of human activity" (p. 106), and its development is through the instrumental use, linked to symbolic and material mediation, in the action of sharing tasks in productive relations. He also states that the instrument is the object, which favors the human action to a given purpose, by being configured as "the carrier of the true conscious and rational abstraction, of the first conscious and rational generalization" (p. 88). According to the author, the symbolic action occurs at a superior level of intellectual activity through the use of the real instrument (concrete) and the sign (symbolic instrument), configuring itself as a specific characteristic of man.

The work relations are established, in this perspective, as essential to the development of the characteristics, which compose the superior psychic functions, characterizing the human action as the one developed collectively, through the cooperation between men and that supposes a technical division of work activities (Leontiev, 2004). Such characteristics are only distinguished from collective tasks of animals through the peculiar way with which the men interact to perform an action of work: through the use of instruments and the communication as symbolic mediators that favor the reflexive and intentional capacity of actions with the nature. 
To strengthen this argumentation, Leontiev (2004) establishes the aspects, which differentiate the animal activities from those eminently human. For this author, the animal activity is developed to an instinctive and biological degree of relation between the animals, usually oriented to satisfy the rudimentary needs, promoting the psychic development at an elementary level. As to human activities, they suffer a qualitative transformation through the contents inherent to work operations, differentiating themselves through the conscious capacity to create and use the instruments to work (Leontiev, 2004).

In summary, the instrumental activities occur among the different species, but it is only among men that the work acquires character of social process through the possibility of development of intentional (conscious) actions inherent to human activities developed collectively and that, in essence, are feasible through language and thought. Therefore, the qualitative development of psychic functions, which demarcate distinction with the animals, is in the differences attributed to the social organization of work among the diverse species.

According to Vygotsky (1998), the use of instrument is related to the creation of the system of signs by human culture, for exerting the mediating function of thought, communication and social work. By approaching the relation between human intelligence and the use of signs, this author established that "the dialectic unity of these systems in the adult human constitute the true essence of human complex behavior" (p. 32). The mediation processes are directed related to the use of signs and, according to Vygotsky, occur through the internalization of the external aspects to the subject, favoring, this way, the development of human psychological functions.

Based on these assumptions, it understood that the development of superior psychic characteristics occur through the dialectic action in which the man, intentionally, changes the nature and is changed by nature itself. The shared tasks in productive relations favor the changes in the natural world and, through this, there is a re-organization and a new level of development of human psychological functions (Vygotsky, 1998, 2000).

These and other propositions from the historical-cultural psychological approach enable the thought about the contemporary spaces as the locus for the elaboration of formative processes, which target the human development, under a systemic, dynamic and relational perspective, and that reveal a more complex vision on the formation of competences of man to the desired work and professional profile by a given culture. The theoretical considerations conducted throughout this section intend to raise reflections on some of the main theoretical perspectives of the approach by competences and the unfolding to a more contemporary understanding of this concept.

\section{Approach by Competence and Historical-Cultural Psychology: Possibilities of Articulations}

In the last decades, there were changes in social, historical, economical and cul- 
tural aspects, bringing new nuances to the way with which man have been interacting and establishing relationships, especially in situations concerning professional work. With the transformation of factors related to human production, the work organizations have been gaining structural and functional contemporary configurations, redefining the professional profile and conferring more complexity to the matter of professional competences (Araujo, 2003; Marinho-Araujo \& Almeida, 2017; Marinho-Araujo \& Rabelo, 2015).

The technological advancement of work organizations have been generating fast advancement in the contemporary society, making emerge thematic discussions on work and education, specially relating the professional formation. The approach by competence has been evidenced in this debate due to its pertinence to the understanding of the development of professional subjects, through distinct theoretical perspectives and fields of knowledge.

The competence is a conceptual construction, which permeates the discussions in several areas of the social sciences and, more recently, has been a subject of study and intervention in the fields of Education, Health and Psychology (Manfredi, 1999). Tejada (2008) states that different classic theories in Psychology establish the foundations for the evolution of notions of competences. The author highlights Chomsky, in relation to the linguistic competences; Piaget who, through the experimental genetic psychology, proposed the understanding of competences through the perspective of human intelligence; North-American authors, such as Thorndike, Watson and Tolman, for the behavioral propositions on the behavioral evolution; and, in the end, Vygotsky, for the understanding of development through the historical and social processes. In the case of this last approach, Tejada (2008) emphasizes contributions to the concept of human competences associated to a perspective of learning and development.

More recently, the field of School Psychology, based on the historical-cultural perspective, has brought significant contributions on the theme of competence development, by understanding this process as conducive to the constitution of human psychological functions (Araujo, 2003). In the institutionalized contexts to the practices of education, the emphasis is directed to the strategies of educators formation by which professional competences are established to constitute a profile capable of dealing with dynamic educative situations, uncertain and that meet pedagogic-institutional specificities. To understand the articulations between the knowledge of School Psychology, as a field committed to the human development, and the approach by competences, as a privileged methodological instrumental to the formation of social educators, is required to understand how the concept of competences was influenced by historic transformations of work.

For Le Boterf (2003), Zarifian (2003) and Wittorski (1998), the theoretical conceptions and models attached to the notion of competence are a long-term change, which opens a new post-modern historic period, with a new comprehension of human and world. This model suppresses two historic dominant models: 1) the model of profession, by which concentrates characteristics of re- 
lation hierarchy ("from the apprentice to the master"); social identity of the profession; learning through a succession of tests; focus on the quality and originality of the product; local monopoly of distribution; institutionalization of professional exercise; and 2) the model of workstation, which was created under the aegis of Taylorism in the context of the age of big industries in reason of the necessary socioeconomic restructuring of the countries (Le Boterf, 2003; Zarifian, 2003). In this first period, during which the matter of competence emerged, it is noted that it comes implicitly from a deep societal change, at the heart of emergence of new social aspirations.

According to Zarifian (2003), it was from the liberalistic conjuncture of society in the French context, by the 70's, that the new model of competence emerged based on criteria of autonomy and responsibility. From this new order, the individuals were rated according to the job they had. With the adhesion to the criteria of autonomy and responsibility, the individual was considered more qualified and the autonomy to work is bigger.

In the 80 's, period in which the French society tried to eliminate an economic crisis, new productive and concurrent challenges impacted on the conception of competence. In this sense, this concept started to aggregate two underlying elements to overcome the economic crisis. First, the better quality of products, personalization of relation to the clients and more complexity in performance influence an understanding of competence based on power distribution to basic teams. Secondly, with the constant growth of market uncertainties, the competences started to assume a comprehension of local responsibility, from a necessary knowledge to decision making in unexpected circumstances (Zarifian, 2003). In the means that the performances became more complex and focused on the relation with the client as a start point, new social and cognitive dynamics emerged. Work for competence, from now on, would be to confront a problem and improve the search for solutions.

From the 90's on, the priority was directed to a reorganization of business structure in terms of reducing the costs and increasing the profitability, period of unfavorable economic conjuncture where the occidental countries tried to line up to the consensus precepts of Washington (Montãno, 2003). Under the pretension of reducing public and private costs, it was a period in which the organizational innovations were left in the background and, therefore, the thematic of competences did not show advancements in this scenario. It was only by the end of this decade that the theme emerges again, from a perspective to rescue the subject involved in the productive processes, where the model of competence counterposes the model of workstation.

For Zarifian (2003), three social aspects were relevant for this change in paradigm to understand the competence during this period: 1) the emergence of individuality, characterized by the appreciation of the worker in the social activity of work; 2) the interdependence of collective work, which flows each time fewer mechanically, involving the subjectivities of subjects implicated in interaction 
and communication webs more diversified and complex; and 3) the dynamic and complex world, whose uncertainties provoke a change in definition of the worker's profile. The competence, therefore, does not appear without the mobilization of a wide range of organization resources and the subject's own resources to deal with unusual situations. In this sense, the development and the mobilization of competences are not attached predominantly to the technologies and organizational structures, conferring to the subject an active role in his/her subjective implication with the work (Zarifian, 2003; Le Boterf, 2003).

For Le Boterf (2003), in this social conjecture, the competence started to be understood as the own mobilization of resources to administer a complex professional situation and for which the individual was not prepared. The notion that the professional competence is associated to the mobilization of resources is constituted as a still ascending conception in the contemporary societies, due to continuous transformations, which configure social organizations of work each time more diversified and complex. In conceiving the notion of competence as a social construct with varied meanings, it is necessary to emphasize how this concept influenced the orientation, planning and curricular organization of professional formation models (Deluiz, 2001; Kuenzer, 2003).

The current formative processes comprehend the development of professional competences based on an ethical conception, emancipatory and autonomous of individual, whose professional commitment is directed to social change (Marinho-Araujo \& Almeida, 2017). The educative strategies to build social competences to work shall consider the aspects of subjectivity, developed in the individuality and collectivity of the individuals, in order to privilege a critical politi$\mathrm{cal}$ and social formation, which suppress the professional conditioning generated by power relations and relations established by the capitalistic society.

In accordance with this comprehension, Tardif (2002) emphasizes the historic dimension of personal and professional life to the development of competences, highlighting the temporal character in the process of consolidation of competences in the professional history. The individual re-signifies continuously and dialectically his/her competences over his/her development, in the interplay of shared social relations. For this, the author considers that the formation of competences is a process with continuity and breakdowns through which ambivalent and oscillating feelings on a profession accompany the professional exercise and affect the formation of the identity to work. Kuenzer (2003) also draws the attention to the matter of temporality in the development of competences, emphasizing the relevance of practical experience.

With the emergence of the critical and emancipatory of development proposition, the adopted conception of competence encompasses the contemporary theoretical foundations of School Psychology, understanding its commitment to the building of knowledge on the mediation in human development. From the understanding of the formation of competences as the own development of human psychological functions, the School Psychology is considered a contempo- 
rary field, which adds up to the theoretical and empirical debates on the development and assessment of competences, corroborating the fields, which consider the individual, historical, social and economical factors as constituting elements of the individual adults in the world of work.

In this research, a proposal of instrument to assess competences confers emphasis to the conceptual expansion of competence notion proposed by Araujo (2003). Based on the historical-cultural perspective in Psychology, the author states that is through the process of mediation that the development of competences is constituted, with special emphasis to the affective and cultural dimensions as factors pertinent to the history of personal and professional formation of individuals.

The NGOs are historically true locus of social educators. In this sense, it is important to invest in the identification of the professional profile required to work at these contexts, considering the historical, philosophical, political and ideological characteristics, which mobilize and originate recent scenarios with a socio-educative function in the country. In this direction, proposals of capacitation and continuous formation for this recent profession shall be linked to this understanding of competence for the work of the social educator and identify the specificities $\mathrm{f}$ his/her professional profile in the space of informal education.

\section{Method}

The adopted method in this investigation consisted in the research-intervention, which involves different investigative actions and of prioritizing goals. The research-intervention adopts an emancipatory practice and a transforming action targeting the autonomy and liberty in the investigative process (Flick, 2009). This kind of research intends to investigate the life of collectivities in their qualitative diversity, which involves an investigation of socio-analytical character based on the historical-cultural approach.

The central aspects, which direct the development of the research-intervention as a transformation device are the change in parameters of investigation related to the researcher's neutrality and objectivity; another aspect refers to the simultaneous production of the individual and the object, questioning the place historically intended to the psychologist, emphasizing the analysis of the implications of affective, professional, political and institutional links, which crosses the formation process.

The understanding of the process of developing professional competences emphasizes the factors, which are related to the formation of superior psychic functions, considering the professional acting area as a fertile locus for a better approximation to the researcher's intended study phenomenon. In this research, it is considered that, through the knowledge about the characteristics of the institution, which develops the social education and the educator's professional profile in these context, be of significant relevance the study of the mediation process in School and Educational Psychology along with the educators in the 
context, through the advisory to the work in service (Marinho-Araujo \& Almeida, 2010).

\subsection{Research Environment and Participants}

The research was conducted in a NGO CAFDS, a non-profit institution, administered and supported by the Educative Association São Francisco de Assis, administered by capuchin friars minor, located in the city of São Luís-Maranhão in Brazil. It is an institution, which directs its activities to children and adolescents from the local community, to whom educative assistance is offered.

By studying the history of the institution, it was found that it was once composed of 5 unities situated in several neighborhoods. Currently, there is only the Alto do Pinho and the Vera Cruz poles, which concentrated their activities due to a period of major financial crisis, which affected its maintaining entity. The two unities possess 8 educators, and the activities developed by them are conducted in multi-serial rooms. The daily routine begins at 2:00 PM, including the moment of reception, when they start a prayer and singing and, after this, classroom related activities, which last approximately 3 hours, with the possibility of short break for a collective snack (however this is not possible everyday due the lack of resources) and, when this is not possible, an individual snack (which is not offered by the institution).

All classes are heterogeneous, with different students considering age and school years, considering that the most important step is the achievement of home tasks directed by regular schools, which are assisted by the educators form the center. By the end of this step and with the possibility of time, extra activities may be conducted. The educators are dwellers from the own community in which the project is conducted and possess socioeconomic conditions similar to all other members from the community assisted by the institution.

The conducted work is sustained through the help by benefactor families from Italy, which give financial support to maintain the activities in the NGOs. The donations are collected and managed by the capuchin friars minor from Italy and are sent to Brazil with the purpose of sustain the project. Initially, its direction was composed by Italian friars, who lived in São Luís, and consisted of 17 educators from 5 poles, a general coordination, and a general manager. Currently, the direction is composed by 8 educators, 2 pedagogic coordinators and the general management by a Brazilian friar.

Along two years, general meetings occurred with the purpose of changing the administrative staff. In the management of 2004-2005 and 2006 and 2008 it was chosen as the first Brazilian manager, friar C., to take charge of the administrative and financial activities of the institution. The research began during the second year of administration by friar C., in 2016. During the first contacts, it was noticed that the institution experiences a financial recession, occasioned by the cut in donations by volunteers from the project. This situation resulted in the extinction of the other unities and culminated in the participation of the social 
educators, who remained in the institutions: six participants in total.

\subsection{Procedures and Instrument}

With the purpose of scrutinizing the research field and be aware of the educators' performance in the educative context, the variables were analyzed in two steps. At first, the institutional mapping was conducted through a documental analysis, in order to characterize the context, and the indicators of the educators' profile. Then, the observation of activities in the classroom, a classic step in research, had the goal of knowing about the characteristics of the educators' performance in practice.

In the documental analysis, access to the meeting minutes was possible and they contained records concerning the establishment of the units. The application of this practice helped to achieve the understanding of both previous and current history, which allowed the study of indicators. The observation was intended to know about the exercises in classroom and all about its surrounding context. In the end, observation reports were made and they described the physical environment, the social interactions and analytic impressions by the observer.

The second step concerned the elaboration and application of a self-assessment tool of the social educators. This protocol was derived from the proposal of delineating the professional profile of social educators by Soares (2008), besides expanding the literature review on this professional who, in Brazil, still is characterized by a poorly defined profile before the challenges imputed in his/her work nature (Caro \& Guzzo, 2004; Soares \& Marinho-Araujo, 2010).

The protocol is based on the proposal of conceptual expansion of the notion of competences by Araujo (2003), which considers it a diverse set of individual and sociocultural resources, mobilized with the intent of the individuals being trained or performing professionally, aiming at solving a problem. These competences presuppose the integrality of cognitive, emotional and social dimensions, articulated to the formal theoretical knowledge on the formation of professional trajectories.

The need to conduct an assessment with a more dynamic and formative character to surpass a technical perspective in the evaluation of competences, besides the conceptual expansion, is relevant to privilege the conceptions of the individuals in focus, as well as the spaces in which the individuals are inserted. Starting from the reflections on School Psychology and Social Education, this protocol suggests an initial profile of the professional profile desired for the social educator in NGO. This is a categorization proposal of expanded competence resources by Soares (2008) and targets the assessment of competences for acting according to the demands, functions and work responsibilities in the context of the informal education.

As a first exercise to elaborate the profile's design, it was necessary to reflect on the influence of symbolic mediation as a central conceptual subsidy for the 
intervention of the school psychologist in the processes of adult development. In this sense, to consider the transformation of the most complex psychological functions for the continuous formation may offer essential indicators for understanding the symbolic, concrete, affective, operational and strategic means by which the individuals' competences are built. For this, it is important to consider the psychological intervention in human formation as process of consciousness of roles, attributions, responsibilities, pertinent to the professional work.

For the analysis of individual as the main means for understanding the competence development processes, in counterpoint to the emphasis on task, it is important to consider as target of analysis, the epistemology of action (Araujo, 2003) of the participants involved in this formation. This conceptual contribution is useful for understanding that the reflection processes of action, on action and to action are defined as resources linked to the production and expansion of new psychic functions for human work and, therefore, the own formation of competences. The paths to the development of the professional's profile, as a dialectical process of awareness taking for the capacitation, constitute, this way, the investment in this research-intervention, aimed to identify the necessary profile and competences for a better preparation of social education professionals for this emergent educative space. For this, two central axes were oriented in this first exercise in specifying the social educators' profile: the nature of competence, this is, to any situation, action or problem, and the resources for the collective and individual competences, defined through the usage value and context of the demand (Araujo, 2003).

It is worth to reinforce that this profile's design proposes a categorization of competence resources, which is not limited by the characteristics designed here; it is open and flexible to the demands from the course of formation. The goal is that this procedure configures as a guide to self-assessment by the research's participants, aiming to the mobilization of resources to act in complex situations, challenging and innovating for their work in the context of NGO. There are six competence categories designed for the composition of the social educator's profile: 1) theoretic-conceptual competences; 2) technical and scientific competences; 3) competences of political knowledge; 4) interpersonal competences; 5) ethical competences; 6) esthetic competences. Each of the mentioned categories adds a set of resources, according to Table 1, as follows.

\subsection{Information Analysis}

It was conducted a descriptive analysis of qualitative data related to the record of frequencies of responses about the professional competences of social educators, according to their perceptions (self-evaluation). The educators responded to the instrument, which assessed their level of development in each one of these professional items of competences on the following Likert scale: 1) "developed"; 2) "undeveloped"; and 3) "not developed". The systematization and treatment of data was made through the Excel software, version 10.0, by grouping the total 
Table 1. Description of competences by category, which compose the professional profile of social educator.

\section{Competences of the Social Educator's Profile}

\section{Theoretical and Conceptual Competences (TCC)}

TCC 1: Knowledge on the theory and practice of social education.

TCC 2: Understanding the origins and characteristics of third sector, difference between formal education, non-formal education (NGO) and informal education.

TCC 3: Knowledge on the history of Social Pedagogy in Brazil and the world and its practice to community education.

TCC 4: Domain of sociocultural knowledge, present in the fields of knowledge connected to human spirit, expressed by the senses: arts, culture, music, dance and sport in their multiple manifestations and modalities.

TCC 5: Domain of socio-pedagogical, involving the skills and social competences, which allow the people to break and overcome the marginal, violent and poor conditions, which characterize their social; exclusion.

TCC 6: Domain of sociopolitical knowledge, highlighting the fields of expressive social and political processes, in the form of participation, protagonism, sociativism, cooperativism and entrepreneurship, income generation and social management.

TCC 7: Knowledge on Psychology and Education relationship.

TCC 8: Knowledge on Learning and Developmental Psychology and its educational implications.

TCC 9: Knowledge on the planning tools to socio-educative activities.

TCC 10: Knowledge on the regularization of the social educator as a profession.

TCC 11: Knowledge on the national legislation, which underpins the practice of education and social education (LDB, National Curricular Guidelines for the formation of teachers on Basic Education, PCNS among others).

TCC 12: Knowledge on the Participative Planning and its main concepts, such as assemblies, advices, collegiate, among others.

TCC 13: Theoretical-methodological basis on the pedagogical practices in multi-serial classes.

TCC 14: Knowledge on curricular contents of formal teaching and its relations to the unfolding to the non-formal education curriculum.

\section{Technical and Scientific Competences (TSC)}

TSC 1: Domain of instruments to record planned activities during the semester.

TSC 2: Knowledge on pedagogical instruments and techniques for acting in multi-serial classes.

TSC 3: The ability to propose alternative extra classes, which facilitate learning.

TSC 4: The ability to organize the family participation in socio-educative activities, with critical clarity of the distinct functions of NGO and family.

TSC 5: Preparation for the management of play activities for the apprentices' learning.

TSC 6: Individual and group work techniques aimed to a more expanded organization.

TSC 7: Capacity to elaborate educative projects.

TSC 8: Capacity to generate financial and human resources.

TSC 9: Technical knowledge on the implementation of pedagogical actions, aimed to the participation of the family and community in the educative actions of the institution.

TSC 10: Capacity to intervene and resize educative project, based on institutional and communitarian reality.

\section{Practical Knowledge Competences (PKC)}

PKC 1: The ability to solve problems in classroom and other institutional environments, through the mobilization of experiences of teaching practice and socio-educative mediation along with the family and community.

PKC 2: The ability to relate subjects of daily life to socio-educative activities.

PKC 3: Exploration of spaces and extra classroom routines to socio-educative activities.

PKC 4: The ability to mediate the familiar reality in the interface with the proposal of values, principles and philosophy of institution. 


\section{Continued}

PKC 5: Transversal knowledge of the practice to theoretical basis, which subsidize your socio-educational actions.

PKC 6: The ability to mediate religion teaching and moral values with criticism and respect to theological diversity.

PKC 7: Mutual sense of help, stimulating experience and value exchanges between the community's culture and the socio-educational principles of the institution.

PKC 8: Knowledge on community reality of the participants of NGOs.

\section{Interpersonal Competences (IC)}

IC 1: Ability to carry out and motivate collective activities, promoting the team's development and diversity appreciation in levels of knowledge.

IC 2: Availability to receive, evaluate and re-signify the criticism of students, parents and community members over their acting.

IC 3: Ability to mediate conflicts involving students.

IC 4: Subtlety in communication of conflicts, inadequacies and attitudinal misconceptions of students to the parents, as to value the culture of success.

IC 5: Ability to seek solutions to problems through communicative and cooperative abilities.

IC 6: Ability to make the socio-educational activities more flexible, starting with the different levels of students' learning styles.

IC 7: Capacity to work with team in an interdisciplinary way.

\section{Ethical Competencies (EC)}

EC 1: Ability to work on cultural, social and economical diversity in educative space.

EC 2: Availability to remove previous judgments, absolute truths and moral norms in relation to other individuals.

EC 3: Sensitivity and criticism to the educative practice as to not "domesticate" the students the way society would expect in general.

EC 4: Care and zeal to solve prejudiced, stigmatizing and victimizing practices of situations and individuals.

EC 5: Ability to develop the critical vision of the educator over himself/herself and the world in situation of poverty, misery and social injustice.

EC 6: Wit to perceive and criticize relations predominantly assistant and uncritical, which curb the emancipation of the individuals.

EC 7: Tolerance, respect and care of adverse situations to the principles and norms of human coexistence, by acknowledging significant values to the students.

EC 8: Ability to produce the exercise of tolerance, respect and solidarity in their acting.

EC 9: Ability to develop reflections over emergency situations to make decisions.

EC 10: Ability to be open to the development of proximity with the students (free friend).

EC 11: Ability to continuous formation, showing availability to learn and seek alternatives, which aggregate knowledge and growth to their formation.

\section{Esthetical Competences (EsC)}

EsC 1: Sensitivity to not camouflage the diversity and the unequal distances of social and school skills, culture, tastes, preferences and styles among the students, working with focus on respect to ethnical, gender, religion and other differences.

EsC 2: Easiness in presenting work proposals in organized, attractive, pleasurable and motivating way to work with the children.

EsC 3: Ability to stimulate creativity, originality and authenticity to the children.

EsC 4: Sociocultural animation in group and community situations, with the ability to manifest coherent presence and personal style, consistent and appropriate to each professional context.

EsC 5: Ability to propose different activities to traditional methods.

EsC 6: Ability to value diversity and promote discussion spaces.

EsC 7: Ability to promote situations for children's development outside the educative environment.

EsC 8: Ability to create harmonic and provocative spaces for circulation of new senses and new relations.

Authors' own source. 
number $(\mathrm{N})$ of responses for each categorical grouping of competences, for the synthesis of the results, as well as the competence resource. The organization of computed data starting from the number of responses favored a descriptive analysis of this information through the study of graphs and tables (Levin, Fox, \& Forde, 2012).

\section{Results and Discussion}

Next, we present the recurrence of responses for the categories of professional competences, which constitute the professional profile of social educator in two fragments of data organization. First, the grouping of responses is recorded by six categories of competences: 1) theoretical and conceptual competences; 2) technical and scientific competences; 3) practical knowledge competences; 4) interpersonal competences; 5) ethical competences; 6) esthetical competences. In this Figures 1-6 there was generated a total number of responses by category, which are function of the number $(\mathrm{N})$ of items (subcategories) of competence resources. In individual responses by competence resources, the generated number of responses is equal to the number of participants of the research (six), which is distributed among the concepts named "developed", "undeveloped" (little developed) and "not developed" for each competence assessed by the respondent.
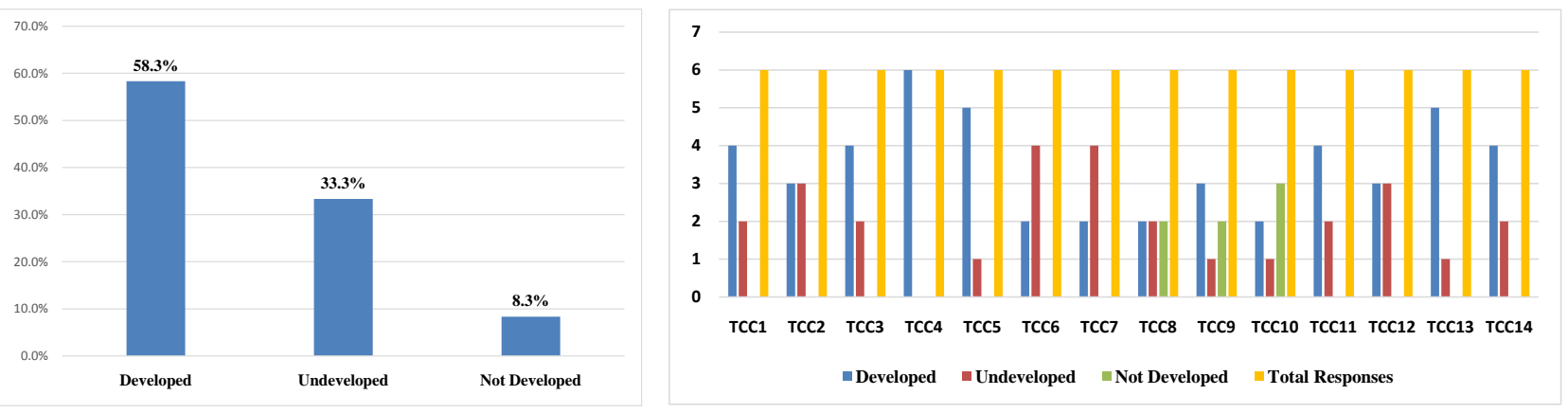

Figure 1. Response percentage by development level of the Theoretical and Conceptual Competences $(\mathrm{N}=84$ responses), to the left; and development level by Theoretical and Conceptual Competence (TCC) ( $\mathrm{N}=6$ responses by self-evaluated item), to the right. Authors' own source.
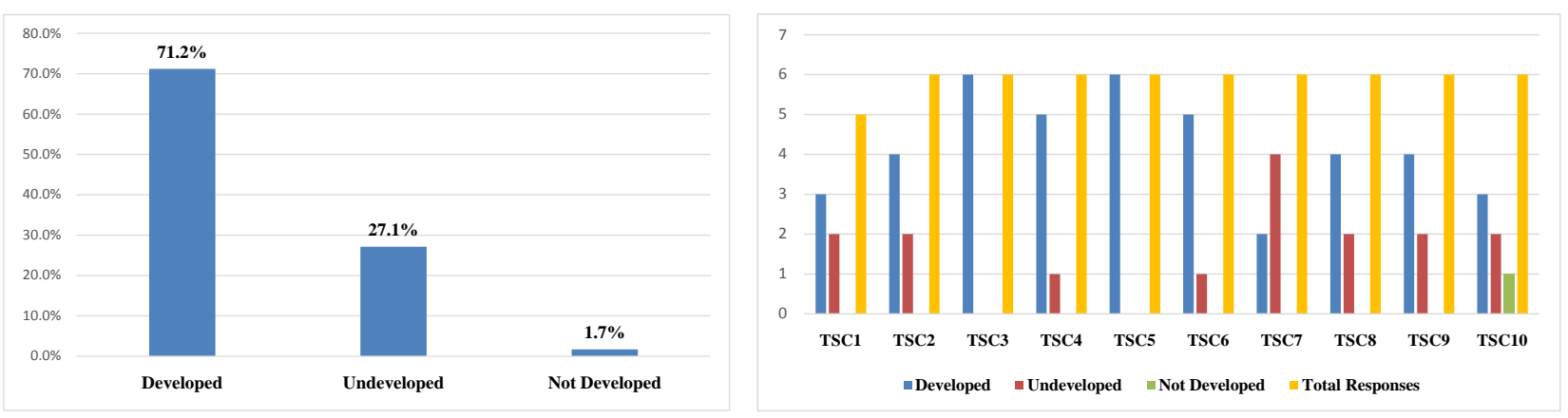

Figure 2. Response percentage by development level of Technical and Scientific Competence ( $\mathrm{N}=84$ responses), to the left; and development level by Technical and Scientific Competence (TSC) $(\mathrm{N}=6$ responses by self-evaluated item), to the right. Authors' own source. 

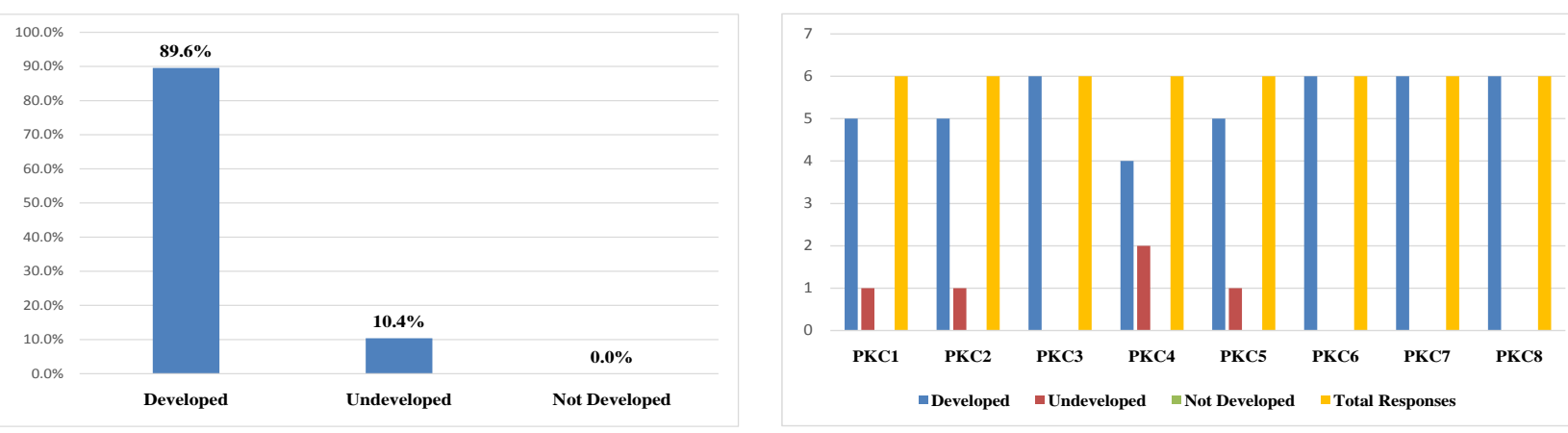

Figure 3. Response percentage by development level by Practical Knowledge Competences ( $\mathrm{N}=48$ responses), to the left; and development level by Practical Knowledge Competences (PKC) $(\mathrm{N}=6$ responses by self-evaluated item), to the right. Authors' own source.
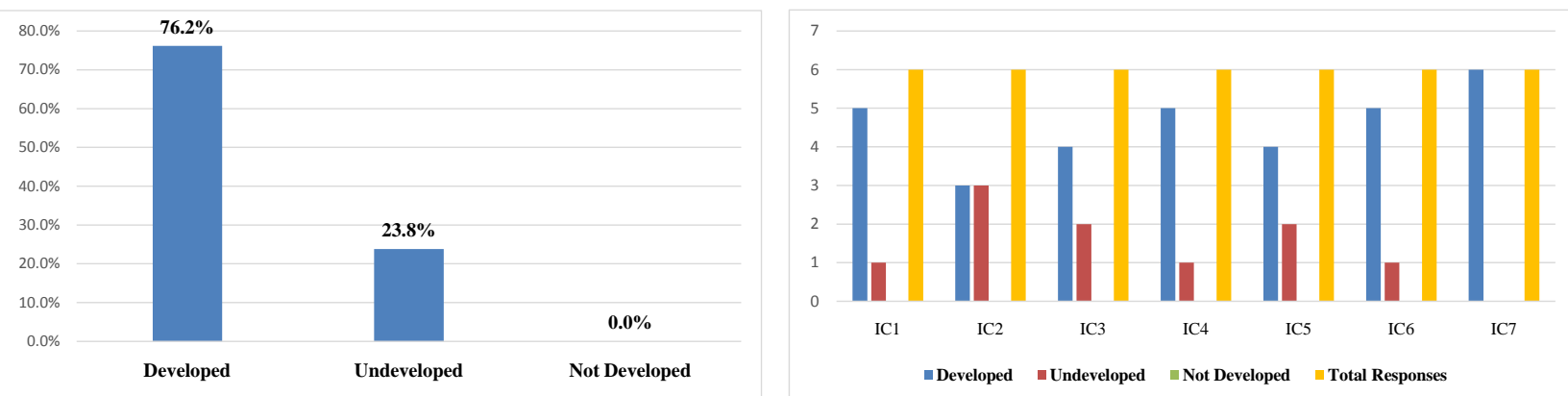

Figure 4. Response percentage by development level of Interpersonal Competences ( $\mathrm{N}=42$ responses), to the left; and development level by Interpersonal Competence (IC) ( $\mathrm{N}=6$ responses by self-evaluated item), to the right. Authors' own source.
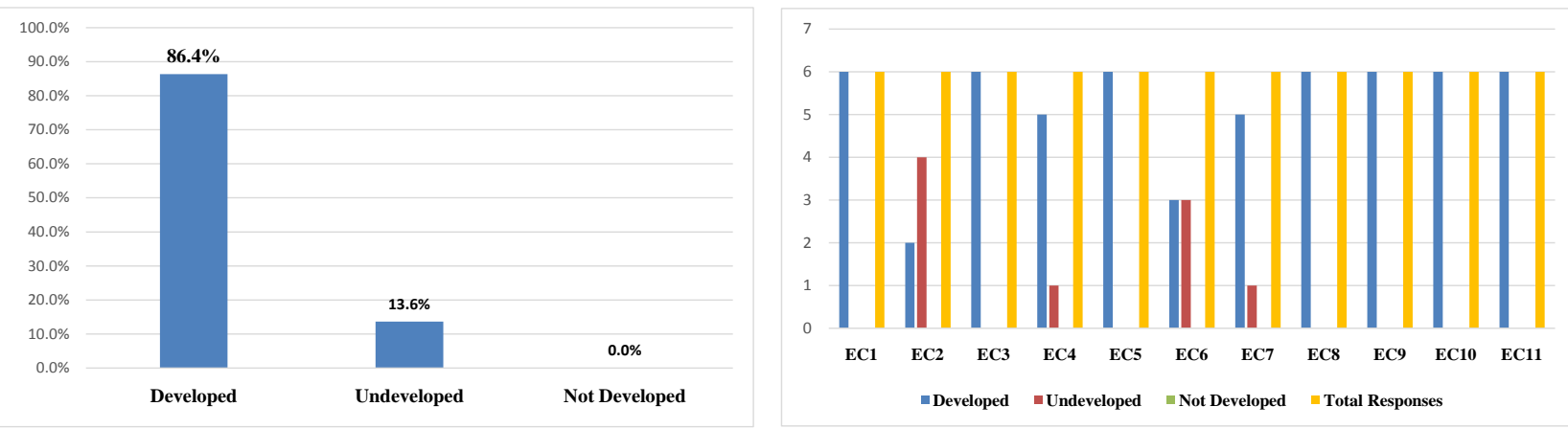

Figure 5. Response percentage by development level of Ethical Competences ( $\mathrm{N}=66$ responses), to the left; and development level by Ethical Competence (EC) $(\mathrm{N}=6$ responses by self-evaluated item), to the right. Authors' own source.
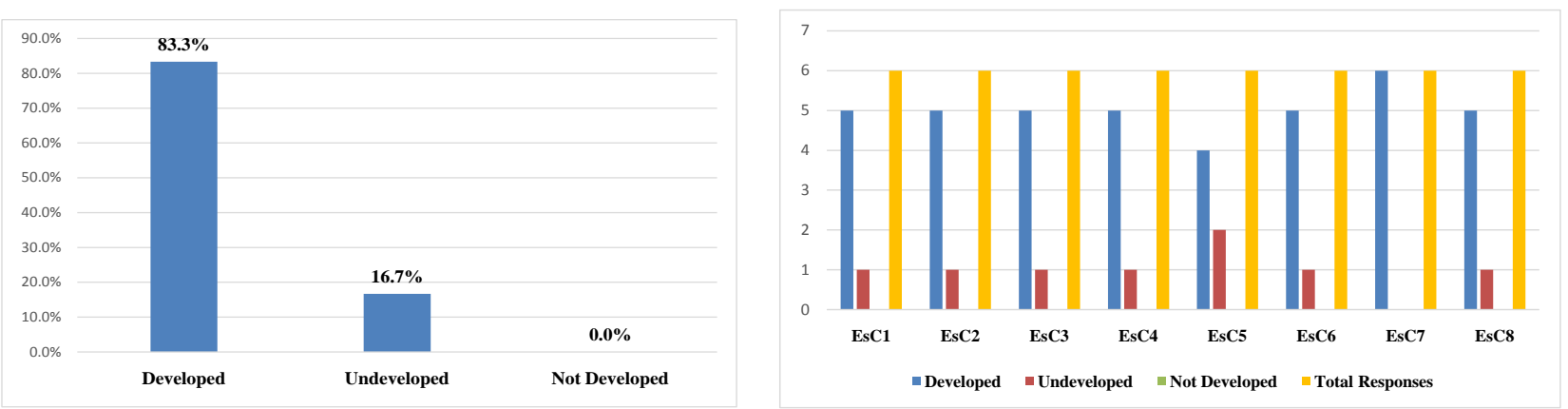

Figure 6. Response percentage of development level of Esthetical Competences ( $\mathrm{N}=59$ responses), to the left and development level by Esthetical Competence ( $\mathrm{EsC})(\mathrm{N}=6$ responses by self-evaluated item), to the right. Authors' own source. 
The results indicated that the educators signalized the development of transversal competences, that is, those related to practical knowledge, to the interpersonal, ethical and esthetical resources and of minor development on technical competences to the formal initial formation, which is based on the development of theoretical and conceptual resources and technical and scientific resources to the profession (Marinho-Araujo \& Almeida, 2017). This, probably, indicates that the lack of specific formation in the field of social education in Brazil may not guarantee safety as to a practice related to the contexts of not formal education, as indicated by the Brazilian studies by Calegare (2005); Caro and Guzzo (2004); Dadico (2003), Dadico and Souza (2010); Dias (2007), Galvão (2014); Galvão and Marinho-Araujo (2017) and Soares (2008).

The discussion on the formation and regularization of the profession of the social educator still is quite recent in Brazil, which still demands more attention to studies, which investigate the proper profile for acting in non-formal education spaces based on these technical competences (Pereira, 2016; Soares \& Marinho-Araujo, 2010). As some of the studies on this worker's history in the country indicate (Dadico, 2003; Gohn, 2006, 2009, 2011; Soares, 2008), the changes in Brazilian education scenario mobilized discussions and debates in relation to these professionals' formation, which are involved in social programs and projects, which involve predominantly the popular society. For this, it is corroborated with a conception of work organization as privileged locus to the complex processes of adult human development. The historical-cultural theory in Psychology conceives the work notion as the angular stone to the development of psychological characteristics typically human, specially anchored on the materialistic and Marxist dialectical assumptions.

Leontiev (2004) brings a more deep discussion on the evolution of the human intellectual processes starting from their understanding on human activity and the relation to the notion of the Marxist work. For this author, "the structure of human consciousness is regularly connected to the structure of human activity" (p. 106), whose development come true through the instrumental use, link to symbolic and material mediation, in the actions of sharing the tasks in productive relations. In this sense, it is defended the continuous formation in service as a privileged means for the development of these important psychological functions for a competent acting, specially of a professional, to whom an identity is still being built (Soares \& Marinho-Araujo, 2010).

The results also indicate a less predominant development of technical competences, suggesting an acting more sustained by principles of solidarity and charity, which reduce the potential of a political and emancipatory action, which need to emerge in alternative education contexts related to popular layers of society (Galvão, 2014). The activities developed in the NGOs by the participants of this research are similar to those conducted in a formal education context, being the main goal the resolution of regular school activities, which provides little preparation for extracurricular activities, which expand the formative character of educational spaces specific to the educational system (Gohn, 2006). 
Also, what is noticed by this research's results is that the exercise by the social educators is marked by love, zeal, dedication and care by actuations sustained by religious beneficence, such it is revealed by the researched institution's profile. The practical knowledge competences, interpersonal competences and esthetical competences comprised a bigger number of respondents indicating they are resources already developed in the profile. Although they are competences of extreme relevance, there may be the risk to develop an empty actuation of militancy with political and emancipatory character, which demands the actuation in the non-formal critical education (Caro \& Guzzo, 2004).

Gohn $(2006,2011)$ highlights that during the beginning of existence of the educative NGOs in the 70's, there existed the institutions linked to the initiatives of religious and civil groups, such as the association of residents, who carried out as priority charity actions and philanthropic basic assistance to attend the local demands by the poorest segments from society. With the changes in the history of NGOs, the educators' professional profiles, characteristic of these spaces of work, needed to be revised. In this direction, Galvão (2014) emphasizes that the assistance work may take to a passive understanding of the individual, who pertains to poor class of society. Such institutions may be favorable locus to the circulation of discourses based on view of the individual as inert victim to the conditions of social inequality. Also, the institutional philosophy of NGOs, which was born from human values of beneficence and care with the others, may weaken when it does not warrant the supply of a pedagogical work subsidized by an understanding of man with potentialities. Not that these qualifications need to be extinct from the profile, but they should not be the only subsides for an actuation supported in the transformation of reality and political mobilization, the main characteristic of NGOs.

Marinho-Araujo and Almeida (2017) highlight the relevance of developing both the technical competences and the transversal competences, considering that the development of a profile committed to social demands is a long process, because it involves the building of a professional history articulated to the personal characteristics and the specificities of professional exercise. The development of competences demands that theories, methods and experiences be articulated in the mapping and solving of problems in daily social and labor context.

The initial and continuous formation seek to rescue the social commitment of NGO, strengthen the role of the agent of transformation and empowering them with technical, practical and theoretical knowledge, concerning the desired profile and competences. The school psychologist's actuation in the formation of the social educator may potentiate their actuation starting from intervention proposals based on processes of consciousness as propellant means to social changes by the critical and emancipatory formation of the learners.

\section{Final Considerations}

The results of the present research have indicated that the transversal competences (interpersonal, ethical and esthetical resources) are better developed than 
technical competences (theoretical-conceptual and technical and scientific resources), which are related to initial and continuous social educator's formation. As discussed along the sections, the way by which the social educator started at Brazilian NGO was, largely, through non-formal and voluntary work to assist the less favored population (Gohn, 2009). On the other hand the participants from this study in special possess many years of experience in this profession, whose knowledge of practice enabled them to develop the transversal competences, very important for the actuation with children and adolescents from periphery.

The instauration of differentiated educative contexts of this nature means the establishment of privileged spaces for the professional formation of committed adult individuals with the transformation of reality. What is observed, against the precariousness of formation in this field, is that urge formative strategies directed to the development of competences of the social educators, targeting the constitution of resources (theoretical, technical, practical, interpersonal, ethical), which mobilize a critical and political actuation in the contexts of combat against social problems (Araujo, 2003; Marinho-Araujo \& Almeida, 2017).

The processes of consciousness are brought as an intervention proposal from School Psychology, specially aiming at the development of a critical view, emancipating and transforming the individuals involved in educational contexts (Galvão, 2014; Guzzo, 2003, 2005; Araujo, 2003; Marinho-Araujo \& Almeida, 2005). The mediator goal of the school psychologist must be to produce more clarity and lucidity in the roles developed by authors from educative contexts, as to optimize the social relations in course to the critical-emancipatory development of individuals.

In this sense, it is defended, as specificity of this field, the elaboration of interventions directed to the subjectivities and inter-subjectivities developed in educative spaces, to break the ideological and crystallizing aspects of social relations, which make the development of the initiative and autonomy of the individuals more difficult, especially those who are victims of a excluding and classist social system.

The propositions from historical-cultural Psychology may contribute to the discussion on the development of ethical competences, which form critical social educators confident about the relevance of their contributions to the social panorama, committed to the emancipatory development of the individuals and with the suppression of social injustices (Vygotsky, 2000; Luria, 1990). To consider the affective and relational aspects of the formation process of independent professionals, confident and conscious about their ethical and political role is very worthy for a proposal of intervention from School Psychology, which prioritizes the personal and professional development of educators through the processes of consciousness on their responsibilities, roles and functions as ethically committed actors to the transformation of their reality (Galvão \& Marinho-Araujo, 2017).

Limitations were found in this study concerning the number of social educa- 
tors and the quantitative scope of institutions of non-formal education. It is important that future researches give relevance to the aspects of diversity of non-formal educative contexts, the diversity of the public, which the NGO serve, as well as the possibilities of intervention in School Psychology in the formation of the social educator's profile regarding psychological knowledge.

In this direction, it is important to highlight the proposal of actuation in School Psychology along with the social educators by Galvão \& Marinho-Araujo (2017), which propose the following actions to the accompaniment to collective work of these professionals and, consequently, the profile's formation:

- Elaboration of meetings, pedagogical workshops and case studies, which are constituted in spaces for interlocution and group reflection on the pedagogical work conducted along with the educators, family, school and community, giving incentives for the sharing of successful actions and the challenges to overcome.

- Creation of spaces for psychological listening to the educator, in individual and/or collective moments, provoking the awareness taking on the potential for the reinvention of educative practices, as well as the re-signification of the view over the process of teaching the educators.

- Elaboration of workshops aimed at, specifically, potentiates the intentionality of the team as to the planning and achievement of educative activities, so the actions of success are less punctual and became results of the goals from the work previously delineated.

- Accompaniment and incentive to the collective moments of theoretical studies articulated to the case studies derived from daily institutional life, aiming at the development by empowering the educator in specific situations to overcome problems.

- Elaboration of formation proposals of the social educators, based on knowledge from Psychology, aiming at oxygenate the conceptions on the educator pertaining to the popular class, as to build a notion of historical individual and protagonist of his/her formation.

- Incentive to the articulation of the knowledge of practice of the social educator, his/her knowledge on the community reality of the learners and the solving of tasks and problem situations in classroom and pedagogical intervention with the family and community.

The theoretical reflections of School Psychology and the notion on competences proposed by Araujo (2003) and Marinho-Araujo and Almeida (2017) discussed in this manuscript, added to the results from the current study, were aimed to expand the conceptions, which form the propositions of initial and continuous formation of the workers from social education. The work characteristics of social educator in the contemporary scenario of non-formal educative institutions are relevant for the actuation and intervention from School Psychology, specially committed to the adult development in contemporary contexts of educational practices. 


\section{References}

Araujo, C. M. M. (2003). Psicologia escolar e o desenvolvimento de competências: uma opção para a capacitação continuada. [School Psychology and the Development of Competences: An Option to Continued Capacitation.] Tese de doutorado não publicada, Brasília: Universidade de Brasília.

Calegare, M. G. A. (2005). A transformação social no discurso de uma organização de terceiro setor. [Social Transformation in the Discourse of a Third Sector Organization.] Dissertação de mestrado não publicada, São Paulo: Universidade de São Paulo.

Canastra, F., \& Malheiro, M. (2009). O papel do educador social no quadro das novas mediações socioeducativas. [The Role of the social Educator in the Framework of New Socio-Educational Mediations.] Actas do X Congresso Internacional Galego-Português de Psicopedagogia. Braga: Universidade do Minho.

Caro, S. M. P., \& Guzzo, R. S. L. (2004). Educação social e psicologia. [Social Education and Psychology.] Campinas: Alínea.

Dadico, L. (2003). Atuação do psicólogo em organizações não governamentais na área da educação. [The Work of Psychologists in Non-Governmental Organizations in the Educational Field.] Dissertação de mestrado não publicada, São Paulo: Universidade de São Paulo.

Dadico, L., \& Souza, M. P. R. (2010). Atuação do psicólogo em organizações não governamentais na área da educação. [The Work of Psychologists in Non-Governmental Organizations in the Educational Field.] Psicologia, Ciência e Profissão, 30, 114-131. https://doi.org/10.1590/S1414-98932010000100009

Deluiz, N. (2001). O modelo das competências profissionais no mundo do trabalho e na educação: Implicações para o currículo. [The Model of Professional Competences in the World of Work and Education: Implications for the Curriculum.] Boletim Técnico do SENAC [Publicação eletrônica], 27. http://www.senac.com.br

Dias, C. S. (2007). Educação não formal e emancipação humana sob o olhar da psicologia. [Non-Formal Education and Human Emancipation under the View of Psychology.] Dissertação de mestrado não publicada, Campinas: Pontifícia Universidade Católica de Campinas.

Flick, U. (2009). Uma Introdução à Pesquisa Qualitativa (3a. Ed.) [An Introduction to Qualitative Research.J Porto Alegre: Artmed.

Galvão, P. (2014). Psicologia escolar em Organização Não Governamental: Um Estudo sobre o Perfil Profissional. [School Psychology in Non-Governmental Organization: A Study on the Professional Profile.] Tese de doutorado não publicada, Brasília: Universidade de Brasília.

Galvão, P., \& Marinho-Araujo, C. M. (2017). Psicologia Escolar em ONGs: Desafios Profissionais e Perspectivas Contemporâneas de Atuação. [School Psychology in NGOs: Professional Challenges and Contemporary Perspectives of Action.] Revista Psicologia Escolar e Educacional, 21, 467-476. https://doi.org/10.1590/2175-35392017021311177

Gohn, M. G. (2006). Educação não-formal, participação da sociedade civil e estruturas colegiadas nas escolas. [Non-Formal Education, Civil-Society Participation and Councils Structures in the Schools.] Ensaio, 14, 27-38. https://doi.org/10.1590/S0104-40362006000100003

Gohn, M. G. (2009). Educação não-formal, educador(a) social e projetos sociais de inclusão social. [Non-Formal Education, Social Educator and Social Projects of Social Inclusion.] Meta: Avaliação, 1, 28-43. https://doi.org/10.22347/2175-2753v1i1.1 
Gohn, M. G. (2011). Educação não formal e cultura política: impactos sobre o associativismo do terceiro setor ( $5^{\mathrm{a}}$ ed.). [Non-Formal Education and Political Culture: Impacts on the Associativism of Third Sector (5th ed.).J São Paulo: Cortez.

González Rey, F. (2003). Sujeito e subjetividade: umaaproximaçãohistórico-cultural. [Subject and Subjectivity: A Historical-Cultural Approach.] São Paulo: Pioneira Thomson Learning.

Guzzo, R. S. L. (2003). Educação para a liberdade, psicologia da libertação e psicologia escolar: Umapráxis para a liberdade. [Education for Freedom, Psychology of Liberation and School Psychology: A Praxis for Freedom.] In S. F. C. de Almeida (Ed.), Psicologia escolar: Ética e competêncianaformação e atuaçãoprofissional (pp. 169-178). Campinas: Editora Alínea.

Guzzo, R. S. L. (2005). Escola amordaçada: compromisso do psicólogo com estecontexto. [School Gagged: The Psychologist's Commitment to This Context.] In A. M. Martinez (Org.), Psicologia escolar e compromisso social: Novosdiscursos, novaspráticas (pp. 17-29). São Paulo: Alínea.

Kuenzer, A. Z. (2003). Competência como práxis: os dilemas da relação entre teoria e prática na educação dos trabalhadores. [Competence as Praxis: The Dilemmas of Relation between Theory and Practice in Workers' Education.] Boletim Técnico do SENAC, 29, 1-16. http://www.senac.br/

Le Boterf, G. (2003). Desenvolvendo competências profissionais. [Developing Professional Competences.] Porto Alegre: Artmed.

Leontiev, A. (2004). O desenvolvimento do psiquismo (2a ed., R. E. Frias Trad.). [The Development of Psyche (2nd ed., R. E. Frias Tran.).J São Paulo: Centauro Editora.

Levin, J., Fox, J. A., \& Forde, D. R. (2012). Estatística para as ciências humanas (11 Ed.). [Statistics for Human Sciences (11th Ed.).] Pearson: Yorkshire.

Luria, A. R. (1990). Desenvolvimento cognitivo. [Cognitive Development.] São Paulo: Ícone.

Manfredi, S. M. (1999). Trabalho, qualificação e competência profissional: Das dimensõesconceituais e políticas. [Work, Qualification and Professional Skill-Political and Conceptual Dimensions.] Educação e Sociedade, 19, 13-49.

http://dx.doi.org/10.1590/S0101-73301998000300002

Marinho-Araujo, C. M. (2014). Intervenção imstitucional: Ampliação crítica e política da atuação em Psicologia Escolar. [Critical and Political Expansion in School Psychology.] In R. S. L. Guzzo (Ed.), Psicologia escolar: desafios e bastidores na educação pública (pp. 153-176). Campinas: Alínea.

Marinho-Araujo, C. M., \& Almeida, L. (2017). Abordagem de competências, desenvolvimento humano e educação superior. [Approach to Competences, Human Development and Higher Education.] Psicologia: Teoria e Pesquisa, número especial, 32, 1-10.

Marinho-Araujo, C. M., \& Almeida, S. F. C. (2005). Psicologia escolar: Construção e consolidação da identidadeprofissional. [School Psychology: Construction and Consolidation of Professional Identity.] Campinas: Alínea.

Marinho-Araujo, C. M., \& Almeida, S. F. C. (2010). Psicologia escolar: construção e consolidação da identidade profissional. [ School Psychology: Construction and Consolidation of Professional Identity.] Campinas: Alínea.

Marinho-Araujo, C. M., \& Rabelo, M. (2015). Avaliação educacional: a abordagem por competências. [Educational Evaluation: A Competence-Based Approach.] Avaliação, 18, 15-27.

Montãno, C. (2003). Terceiro setor e a questão social: Crítica ao padrão emergente de in- 
tervenção social. [Third Sector and the Social Issue: Critic to the Emerging Pattern of Social Intervention.] São Paulo: Cortez.

Neves, M. M. B. J. (2011). Queixasescolares: Conceituação, discussão e modelo de atuação. [School Complaints: Concept, Discussion and Model of Action.] In R. S. L. Guzzo, \& C. M. Marinho-Araujo (Eds.), Psicologia escolar: Identificando e superandobarreiras (pp. 175-192). Alínea: Campinas.

Oliveira, A. C., \& Haddad, S. (2001). As organizações da sociedade civil e as ONGs de educação. [The Organizations of Civil Society and the NGOs in Education.] Cadernos de Pesquisa, 112, 61-87. http://dx.doi.org/10.1590/S0100-15742001000100003

Pereira, A. (2016). A profissionalidade do educador social frente a regulamentação profissional da educação social: as disputas em torno do projeto de lei 5346/2009. [The Professionalism of Social Educator Professional Regulation Front of Education Social: Disputes around the Project Law 5346/2009.] RIAEE-Revista Ibero-Americana de Estudos em Educação, 11, 1294-1317.

Ribeiro, M. (2006). Exclusão e educação social: conceitos em superfície e fundo. [Exclusion and Social Education: Superficial and Thorough Concepts.] Educação e Sociedade, 27, 155-178. https://doi.org/10.1590/S0101-73302006000100008

Rodrigues, L. A. (2005). O educador "em risco": trabalhando com a infância e a adolescência excluídas. [The Educator "At Risk": Working with Excluded Infancy and Adolescence.] In M. B. Park, \& R. S. Fernandes (Eds.), Educação não formal: contextos, percursos e sujeitos (pp. 67-90). Holambra, São Paulo: Editora Setembro.

Romans, M., Petrus, A., \& Trilla, J. (2003). Profissão: Educador social (E. Rosa Trad.). [Profession: Social Educator (E. Rosa Tran.).] Porto Alegre: Artmed.

Soares, P. G. (2008). Psicologia Escolar e Desenvolvimento Adulto: um Estudo sobre o Perfil de Educadoras Sociais em uma ONG de São Luís-MA. [School Psychology and Adult Development: A Study on the Social Educators' Profile from a NGO in São Luís-MA.] Dissertação de mestrado não publicada, Brasília: Universidade de Brasília.

Soares, P. G., \& Marinho-Araujo, C. M. M. (2010). Práticas emergentes em Psicologia Escolar: A mediação no desenvolvimento de competências dos educadores sociais. [School Psychology in Contexts of Social Education: New Practices.] Revista Psicologia Escolar e Educacional, 14, 45-54. http://www.scielo.br/pdf/pee/v14n1/v14n1a05.pdf

Tardif, M. (2002). Saberes docentes e formação profissional. Petrópolis, RJ: Vozes.

Tejada, A. (2008). Análise de um modelo integral baseado no paradigma da complexidade para a compreensão, definição, avaliação e aplicação das competências). (Analysis of an Integral Model Based on the Complexity Paradigm to the Understanding, Definition, Evaluation and Application of Competences.] Tese de doutorado, São Paulo: Universidade de São Paulo.

Vygotsky, L. S. (1998). A formação social da mente. [Social Formation of Mind.] São Paulo: Martins Fontes.

Vygotsky, L. S. (2000). A construção do pensamento e linguagem. [The Construction of Thought and Language.] São Paulo: Martins Fontes.

Vygotsky, L. S. (2004). Teoria e método em psicologia. [Theory and Method in Psychology.J São Paulo: Martins Fontes.

Wittorski, R. (1998). De la fabrication des competences. [From the Fabrication of Skills.] In R. Wittorski (Ed.), La compétence au travail (pp. 57-70). Paris: Education Permanente.

Zarifian, P. (2003). O modelo da competência: Trajetória histórica, desafios atuais e propostas. [The Model of Competence: Historical Trajectory, Current Challenges and Proposals.] São Paulo: SENAC. 